\title{
Manipulation of Light Environment to Produce High-quality Poinsettia Plants
}

\author{
Diego A. Mata ${ }^{1}$ \\ Instituto de Floricultura-INTA, Floriculture, De los Reseros y Las Cabañas \\ s/n (1686) Hurlingham, Provincia de Buenos Aires, Argentina
}

\section{Javier F. Botto}

IFEVA, Facultad de Agronomía, Universidad de Buenos Aires y Consejo Nacional de Investigaciones Cientificas y Técnicas, Av. San Martín 4453 (1417), Ciudad de Buenos Aires, Argentina

Additional index words. Euphorbia pulcherrima, R/FR ratio, light quality, plant growth regulator, plant architecture

\begin{abstract}
The phytochromes, a family of photoreceptors that maximally absorb red (R) and far-red (FR) light, play an important role in defining the architecture of the plant and consequently its value in the market. In this work, we evaluated the manipulation of light quality as an alternative to the use of plant growth regulators (PGRs) to produce poinsettia plants (Euphorbia pulcherrima Willd. ex Klotzsch) without affecting commercial quality parameters. 'Freedom Red' poinsettia plants were cultivated in two light environments characterized by different $R / F R$ ratios in combination with or without one application of PGR. We used a photoselective film that significantly reduced the FR component of the light and a transparent film to obtain high and low $R / F R$ ratios (5.7 and 1.1, respectively). Plants cultivated under a high $\mathrm{R} / \mathrm{FR}$ ratio were shorter and more compact than those grown under transparent film. Other quality characters like bract and leaf area, dry weight, stem diameter, number of lateral branches, and plant width did not differ significantly between light treatments. Flowering time was slightly delayed in plants grown under a high $\mathrm{R} / \mathrm{FR}$ ratio compared with those cultivated under the control treatment. Additive effects were detected between light quality and PGR factors indicating that light quality manipulation is an alternative strategy to reduce or to replace the use of PGRs in commercial production systems that usually require several PGR applications.
\end{abstract}

Poinsettia (Euphorbia pulcherrima) is an important crop in ornamental horticulture, especially demanded at Christmas time (Snipen et al., 1999). In the temperate regions of the southern hemisphere, this date corresponds to the summer season when warm temperatures and high irradiances promote accelerated plant growth. Under these circumstances, the control of plant height is an issue of big concern to produce plants with high commercial quality. Many growers use plant growth regulators (PGRs) to achieve a desired plant height, but the high cost of PGRs, the restrictions to its commercialization, and the increasing pressure of the consumers to avoid the use of contaminant chemicals in horticulture are good reasons to stimulate the exploration of new sustainable alternatives (Berghage and Heins, 1991;

Received for publication 9 Jan. 2009. Accepted for publication 23 Mar. 2009.

We thank Laura Bullrich, Rolf Röber, Alejandra Ghersa, and Marcelo Yanovsky for their helpful comments on the manuscript and BPI Agri for the provision of the Solatrol film.

${ }^{1}$ To whom reprint requests should be addressed; e-maildmata@cnia.inta.gov.ar.
Clifford et al., 2004; Li et al., 2000; Runkle and Heins, 2002).

Plant height can be affected by the manipulation of light quality, and many successful experiences have been reported in different ornamental species (Kambalapally and Rajapakse, 1998; Li et al., 2000; Mortensen and Stromme, 1987; Rajapakse and Kelly, 1992; Runkle and Heins, 2001). Plants absorb efficiently photons of the red (R) and far-red (FR) regions of the spectrum by specialized photoreversible receptors called phytochromes. The action of the phytochromes is a function of the relative amounts of the active and the inactive forms ( $\mathrm{Pfr}$ and $\mathrm{Pr}$, respectively) established in the plant tissues, and it positively correlates with the R/FR ratios in a wide range of light conditions (Smith, 1981). Low R/FR ratios induce several responses in plants known as shade avoidance syndrome that include the promotion of elongation of internodes, petioles, and leaves; the strengthening of apical dominance; the reduction of branching; and the acceleration of flowering (Smith and Whitelam, 1997). In opposition, high $\mathrm{R} / \mathrm{FR}$ ratios induce physiological responses resulting in compact plant architecture (Mortensen and Stromme, 1987; Rajapakse and Kelly, 1992). These experimental evidences suggest that the increase of the $\mathrm{R} / \mathrm{FR}$ ratio is beneficial to produce ornamental plants with high commercial value, and additionally, it would be a friendly environmental strategy to avoid or reduce the use of PGRs. This hypothesis should be evaluated under realistic production systems before it can be recommended to growers.

Previous reports demonstrate that poinsettia plants are responsive to the manipulation of the light environment reducing plant height under high R/FR ratios (Clifford et al., 2004; McMahon and Kelly, 1990). Unfortunately, low-quality poinsettias were obtained as a consequence of the low irradiances achieved under the photoselective films used in these experiments (Clifford et al., 2004), and consequently limited practical recommendations could be obtained. In this study, we evaluate different architectural and quality components of 'Freedom Red' poinsettia plants cultivated with natural radiation under different $\mathrm{R} / \mathrm{FR}$ ratios in combination with or without the application of PGR using management practices similar to those used by growers around Buenos Aires during the summer season.

\section{Materials and Methods}

Plant material and cultivation. Rooted cuttings of 'Freedom Red' poinsettias provided by a commercial grower were transplanted to $13-\mathrm{cm}$ pots containing a substrate media, similar to those used by local growers, composed of pine bark, river waste, and soil $(2: 1: 1 \mathrm{v} / \mathrm{v})$, and vapor-disinfected. Two weeks later, plants were pinched to six nodes and placed inside experimental chambers at a density of 30 plants $/ \mathrm{m}^{2}$. Plants were cultivated under long-day conditions (14-h light + 10 -h darkness) to promote vegetative growth. At the fifth week, plants were transplanted to $15-\mathrm{cm}$ pots containing the same substrate media and spaced at 10 plants $/ \mathrm{m}^{2}$. At that time, the photoperiod was reduced to shortday conditions (10-h light $+14-\mathrm{h}$ darkness) using black curtains to induce flowering. All plants were irrigated daily using a solution composed of $150 \mathrm{mg} \cdot \mathrm{L}^{-1}$ nitrogen $(\mathrm{N})$ from an $18 \mathrm{~N}-18 \mathrm{P}-18 \mathrm{~K}$ fertilizer plus $50 \mathrm{mg} \cdot \mathrm{L}^{-1} \mathrm{~N}$ from calcium nitrate.

Light conditions and experimental design. Growth chamber frames $(3 \times 0.9 \times 0.9 \mathrm{~m})$ were covered with a neutral transparent plastic film (Treatment T) or with a photoselective film (Treatment S; Solatrol; BPI Agri, Stockton-on-Tees, U.K.) that established low and high $\mathrm{R} / \mathrm{FR}$ ratios, respectively, inside the chambers. To achieve similar photosynthetically active radiation $(P A R)$ levels between treatments, neutral shade covers were placed on the top of the transparent film. R, FR, blue (B) radiation, and $P A R$ were measured at noon on a clear day using a four-channel sensor SKR 1850A (Skye Instruments Ltd., Powys, U.K.) attached to a data logger LI-1400 (LI-COR Inc., Lincoln, NE). Ambient temperature was hourly registered using miniature data loggers (Maxim Integrated Products Inc., Sunnyvale, CA). 
Two experiments were conducted during the summer season in 2 consecutive years: 2007 (Expt. 1) and 2008 (Expt. 2). The experimental design of Expt. 1 was a one-way randomized block ( $\mathrm{T}$ and $\mathrm{S}$ treatments). In Expt. 2, we used a split-plot design with light the main factor and PGR the second factor. Three replicate chambers randomly placed inside a greenhouse were arranged in each experiment. In Expt. 2, four treatments were established: T (transparent film without PGR), $\mathrm{T}+$ PGR (transparent film with PGR), S (photoselective film without PGR), and $\mathrm{S}+$ PGR (photoselective film with PGR). The PGR treatment consisted of one application of $1500 \mathrm{ppm}$ daminozide (B-9) + $1000 \mathrm{ppm}$ chloromequat (Cycocel, BASF Argentina S.A.), two inhibitors of gibberellin (GA) biosynthesis. PGR was applied when the growth curve of control plants ( $T$ treatment) exceeded the maximum target curve defined by UNH FloraTrack for Poinsettia software (Fisher, 2005). A water foliar spray application was performed as a control in Treatments T and S.

Data collection and statistical analysis. Plant height and number of nodes with fully expanded leaves were weekly recorded since the start of the experiments. Average height of plants cultivated under each condition was plotted and contrasted to a target growth curve range (Fisher, 2005). In this model, a maximum value of $25 \mathrm{~cm}$ was set as the target for final plant height (from substrate media level) calculated as 2.5 times the pot diameter and then subtracting pot height. Average length of the internodes was calculated dividing the stem length by the number of nodes. Days to flowering were registered at first cyathia open. Leaf and bract area and plant dry weight (stems + leaves + bracts) were evaluated from plants harvested at the end of the experiments. Plant compactness was calculated as the increase in area and/or in dry weight per unit plant height (van Iersel and Nemali, 2004).

Data were analyzed using analysis of variance and differences among treatment means were tested by Tukey's test $(P \leq$ $0.05)$. Because results were similar and comparable between experiments, only data from Expt. 2 are presented unless otherwise stated in the text.

End-of-day experiment. In a parallel experiment, two groups of plants were irradiated at the end of the photoperiod with a 1-h pulse of R or FR light [R-EOD or FR-EOD, respectively $(\mathrm{EOD}=$ end of day)], and a third group of plants was kept as control without an additional pulse of light at the end of the day. All plants received natural radiation during the photoperiod. The $\mathrm{R}$ pulse was achieved with fluorescent lamps placed behind the photoselective film that established a R/FR ratio of 4.88 . The FR pulse was done with incandescent lamps behind a water filter and red and blue acetate plaques that absorbed almost all $\mathrm{R}$ and $\mathrm{B}$ light and established a R/ FR ratio of 0.03 . The light sources were placed at the southern face of the plants. The treatments were arranged in a completely randomized design with three replicates.

Table 1 . Average daily temperature, photosynthetically active radiation ( $P A R ; 400-700 \mathrm{~nm})$, blue (430$470 \mathrm{~nm})$, red $(\mathrm{R} ; 645-675 \mathrm{~nm})$, and far-red (FR; 715-745 nm) radiation, and R/FR ratio measured inside chambers with a transparent $(\mathrm{T})$ or a photoselective $(\mathrm{S})$ film. ${ }^{\mathrm{z}}$

\begin{tabular}{lcccccc}
\hline & Avg daily & & & & \\
Film & temp $\left({ }^{\circ} \mathrm{C}\right)$ & $P A R^{y}$ & Blue $^{\mathrm{y}}$ & Red $^{\mathrm{y}}$ & $\mathrm{FR}^{\mathrm{y}}$ & $\mathrm{R} / \mathrm{FR}$ \\
\hline Transparent (T) & 26.0 & 414.4 & 44.6 & 41.7 & 38.4 & 1.1 \\
Photoselective (S) & 26.3 & 393.4 & 40.7 & 38.0 & 6.2 & 5.7 \\
$P$ value & 0.264 & 0.365 & 0.129 & 0.068 & 0.004 & 0.004 \\
\hline
\end{tabular}

${ }^{\mathrm{z}} P$ value corresponds to a two-sample $t$ test between $\mathrm{T}$ and $\mathrm{S}$ at $P \leq 0.05$.

${ }^{\mathrm{y}}$ Measured at $1200 \mathrm{HR}$ on a clear day and expressed as $\mu \mathrm{mol} \cdot \mathrm{m}^{-2} \cdot \mathrm{s}^{-1}$.

Plant height and the number of nodes were recorded weekly. Data were analyzed using analysis of variance and differences among treatment means were tested by Tukey's test $(P \leq 0.05)$.

\section{Results and Discussion}

The average daily temperatures inside the chambers did not show significant differences between treatments (Table 1). During the cultivation period, the minimum and maximum temperatures registered were 18.3 and $30.8^{\circ} \mathrm{C}$, respectively. The photoselective film decreased more than sixfold the flux density of FR photons compared with the neutral transparent film; meanwhile, the $\mathrm{R}$, $\mathrm{B}$, and $P A R$ measures were similar between treatments (Table 1). The R/FR ratio under the photoselective film was higher compared with those reported by other investigators using similar materials (Fletcher et al., 2005; Li et al., 2000; Mortensen and Stromme, 1987).

Plant height at the end of the experiments was reduced between $13 \%$ and $17 \%$ for plants cultivated under the photoselective film with respect to control plants in Expts. 1 and 2, respectively (Fig. 1). Similar differences were found by other authors using different ornamental crops (Cerny et al., 2003; Li et al., 2000; Runkle and Heins, 2001, 2002; Wilson and Rajapakse, 2001a, 2001b). Clifford et al. (2004) found that stem extension of 'Freedom Red' poinsettia plants cultivated under a photoselective film was reduced by $20 \%$ compared with the control. However, these results are not strictly comparable with our data because Clifford et al. (2004) manipulated the light environment combining natural radiation with a supplementary lighting system of high-pressure sodium lamps increasing the R/FR ratio between 1.7 and 5.73 when $P A R$ dropped below $200 \mu \mathrm{mol} \cdot \mathrm{m}^{-2} \cdot \mathrm{s}^{-1}$ during the photoperiod. Statistically significant differences in plant height between R/FR environments were detected since the seventh day after the start of the experiments (Fig. 2; $P<0.0001$ ). Although the plants grew until the 85th day, the magnitude of the differences between plants growing under low or high R/FR ratios increased during the first $30 \mathrm{~d}$ (Fig. 2). One application of PGR on the 43rd day reduced the stem extension of the plants up to $15 \%$ (Fig. 2). The PGR effects on stem growth were detected $7 \mathrm{~d}$ after its application reaching the maximum differences between treated and untreated plants 3 weeks later (Fig.

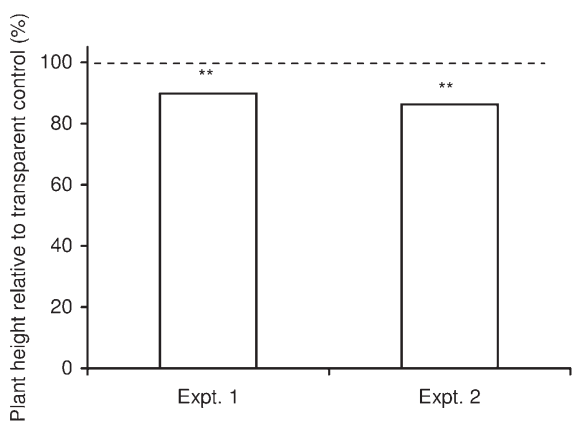

Fig. 1. Plant height relative to transparent control treatment for poinsettia plants cultivated under photoselective film that established a red/farred ratio of 5.7. Data shown correspond to experiments conducted in 2007 (Expt. 1) and 2008 (Expt. 2). Double asterisks (**) indicate significant differences between treatments at $P<0.01$.

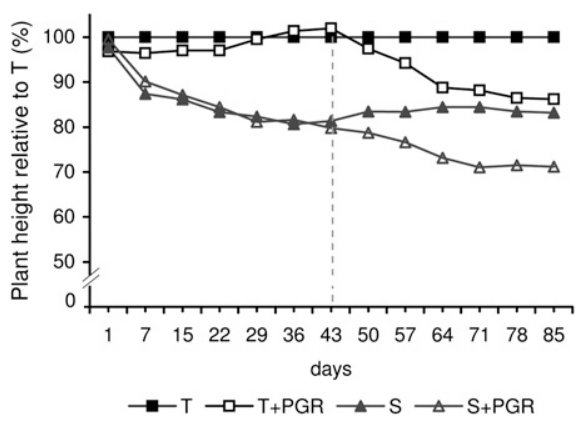

Fig. 2. Time course of plant height relative to transparent control treatment $(\mathrm{T})$ for poinsettia plants cultivated under transparent film plus PGR (T + PGR), photoselective film (S), and photoselective film plus PGR ( + PGR) Vertical dotted line indicates the date of PGR application. $\mathrm{PGR}=$ plant growth regulator.

2). Light and PGR effects were additive and no significant interaction between factors were found $(P=0.585)$. At the end of the experiments, the height of plants cultivated under the photoselective film was similar to those grown under a neutral transparent film with addition of PGR (Fig. 2). These results indicate that the PGR can be replaced by an environmentally friendly alternative like the manipulation of the $\mathrm{R} / \mathrm{FR}$ ratio using photoselective films in poinsettia crops.

$P A R$ reductions could be a limiting factor for the production of high-quality poinsettias under photoselective films (Clifford et al., 2004), especially during the fall and winter seasons at high latitudes. Previous evidence 
demonstrates that a pulse of FR light at the EOD (FR-EOD treatment) is enough to mimic the light environment detected under dense canopies inducing shade-avoidance responses (Smith and Whitelam, 1997). We reasoned that a $\mathrm{R}$ light pulse provided at the end of the photoperiod (R-EOD) would mimic the light conditions of plants growing under the photoselective film without affecting the PAR perceived by the plants during the majority of the photoperiod. In our experiments, we did not observe significant differences in the final height of plants grown with or without R-EOD, although the plants irradiated with FR-EOD were 18\% higher than controls as expected (Fig. 3). Our data demonstrate that the R-EOD treatment does not mimic the light environment obtained under the photoselective film, at least for the variety used in our experiment.

The number of nodes in plants grown under low and high R/FR ratios did not show significant differences. The reduction of plant height was achieved by the inhibition of the extension of the internodes with the correlated increase in the stem diameter (Table 2). This could be beneficial for improving shoot breakage performance, which is an issue of concern in poinsettia pinched plants reaching maturity (Faust and Heins, 1996; Kuehny and Branch, 2000; McDaniel et al., 1990). The number of lateral branches did not differ among treatments and was enough to reach market specifications for the finished product that require at least five laterals for pinched plants (Faust and Heins, 1996). However, other authors found an increase in the number of lateral branches in poinsettia plants cultivated under high $\mathrm{R} / \mathrm{FR}$ ratio (Clifford et al., 2004), and a similar tendency was observed in other ornamental species (Kasperbauer, 1987; Runkle and Heins, 2001). We did not detect differences between treatments in the coloration of the bracts (data not shown). The dry weight and area of all aerial parts were similar between treatments with the exception of plants cultivated under the photoselective film with a PGR application ( $\mathrm{S}+$ PGR treatment; Table 3). The quality of poinsettia plants grown under S + PGR was

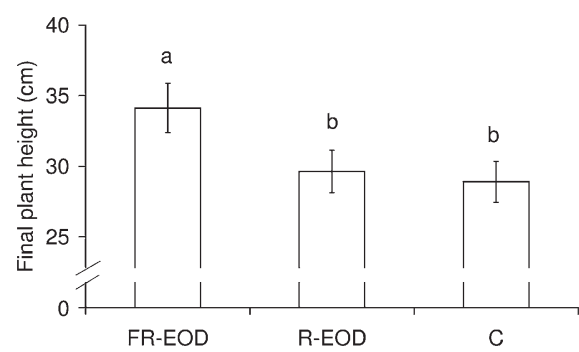

Fig. 3. Final plant height of poinsettia plants exposed to far-red (FR) or red (R) pulses of light at the end-of-the-day (FR-EOD and REOD, respectively). The height of plants cultivated without any additional pulse of light at the end-of-the-day is shown as control (C). Vertical lines represent $95 \%$ confidence interval. Different letters between columns indicate significant differences by Tukey's test at $P \leq$ 0.05 . reduced with respect to other treatments as a consequence of the reduction in the plant diameter and a decrease in the total area (Tables 2 and 3). In addition, dry weight of bracts was reduced under S + PGR (Table 3). Several works reported that the irradiance and the light quality may affect plant parameters like dry weight. For example, no significant differences in dry weight were reported in poinsettia (Clifford et al., 2004) and lisianthus (Wilson and Rajapakse, 2001a), but reductions in plant dry weight were reported for chrysanthemum, zinnia, cosmos, antirrhinum, and petunia under high R/FR ratios (Cerny et al., 2003; Li et al., 2000).

The flowering time was slightly delayed in plants cultivated under a high $\mathrm{R} / \mathrm{FR}$ ratio with respect to control plants, and a similar behavior was observed for plants cultivated under transparent film with a PGR application (Fig. 4). A delay in flowering time has also been reported for many crops cultivated under a high $\mathrm{R} / \mathrm{FR}$ ratio compared with those grown under a low $\mathrm{R} / \mathrm{FR}$ ratio, but the magnitude of this effect depends on the species and/or cultivar (Cerny et al., 2003; Clifford et al., 2004; Rajapakse and Kelly, 1995; Runkle and Heins, 2002). Multiple inputs like photoperiod, light quality, and GA converge to regulate flowering (Mouradov et al., 2002; Simpson and Dean, 2002). Flowering is promoted by the application of GA and mutations that cause constitutive active GA signaling (Jacobsen and Olszewski, 1993); meanwhile, flowering is inhibited in mutants that block GA signaling or GA biosynthesis (Wilson et al., 1992). FR $(730 \mathrm{~nm})$ and $\mathrm{B}(440 \mathrm{~nm})$ promote flowering through phytochrome A and cryptochromes 1 and 2. R $(660 \mathrm{~nm})$ inhibits flowering through phytochromes B, D, and E (Aukerman et al., 1997; Childs et al., 1997; Devlin et al., 1998; Weller et al., 2001). In addition, cryptochrome 2 and phytochrome A are involved in the photoperiodic pathway of flowering acting in the stability of the CONSTANS protein that promotes flowering in a long-day plant such as Arabidopsis (Valverde et al., 2004) and inhibits flowering in a short-day plant such as rice (Izawa et al., 2002).

Many growers use graphical tracking to monitor the growth of their poinsettia crops with the objective of defining the date of PGR application to control the plant height. The graphical tracking is based on whether the average crop height is above, below, or within a target range defined by an upper and a lower growth line. We used a target growth curve range generated by graphical tracking software (Fisher, 2005) to evaluate the growth curve adjustment of plants cultivated in different R/FR and PGR environments. The growth curve of control plants (T treatment) was slightly above the range of the target curve from the start of the experiment and exceeded the plant height goal by $23 \%$ at the end of it (Fig. 5). When PGR was applied to plants cultivated under transparent film (i.e., T + PGR), the growth curve is included in the target range, but close to the end of the experiment, it slightly exceeded the upper limit (Fig. 5). The growth curve for plants cultivated under photoselective film was in the target curve limits and the application of PGR did not show any additional benefit (Fig. 5). These results show that the manipulation of light quality is a complementary strategy to control the height of 'Freedom Red' poinsettia plants under commercial production conditions.

Usually plant height is considered a synonym of plant compactness, but many times both parameters do not represent the same (van Iersel and Nemali, 2004). In this work, we defined a compactness index as an increase in the total area (leaf + bract) or in the total dry mass per unit of plant height (van Iersel and Nemali, 2004). Plants cultivated under a high R/FR ratio had a higher compactness index than control plants, and it was similar to the index of the plants grown under

Table 2. Number of nodes, average internode length, stem diameter, number of lateral shoots, and plant width for poinsettia plants cultivated under transparent film (T), transparent film plus PGR (T + PGR), photoselective film (S), and photoselective film plus PGR (S + PGR). ${ }^{\mathrm{z}}$

\begin{tabular}{lccccc}
\hline & $\begin{array}{c}\text { Number } \\
\text { of nodes }\end{array}$ & $\begin{array}{c}\text { Internode } \\
\text { length }(\mathrm{cm})\end{array}$ & $\begin{array}{c}\text { Stem diam } \\
(\mathrm{cm})\end{array}$ & $\begin{array}{c}\text { Lateral } \\
\text { shoots }\end{array}$ & $\begin{array}{c}\text { Plant width } \\
(\mathrm{cm})\end{array}$ \\
\hline $\mathrm{T}$ & $14.6 \mathrm{a}$ & $1.7 \mathrm{a}$ & $4.3 \mathrm{a}$ & $5.3 \mathrm{a}$ & $30.6 \mathrm{a}$ \\
$\mathrm{T}+\mathrm{PGR}$ & $15.8 \mathrm{a}$ & $1.4 \mathrm{~b}$ & $4.7 \mathrm{~b}$ & $4.9 \mathrm{a}$ & $29.0 \mathrm{a}$ \\
$\mathrm{S}$ & $15.0 \mathrm{a}$ & $1.4 \mathrm{~b}$ & $4.6 \mathrm{~b}$ & $5.6 \mathrm{a}$ & $29.2 \mathrm{a}$ \\
$\mathrm{S}+$ PGR & $14.4 \mathrm{a}$ & $1.2 \mathrm{~b}$ & $4.6 \mathrm{~b}$ & $5.3 \mathrm{a}$ & $24.6 \mathrm{~b}$
\end{tabular}

${ }^{\mathrm{z}}$ Different letters within columns indicate significant differences by Tukey's test at $P \leq 0.05$.

$\mathrm{PGR}=$ plant growth regulator.

Table 3. Dry weight of stem, leaves, and bracts and area of leaves and bracts in poinsettia plants cultivated under transparent film (T), transparent film plus PGR (T+ PGR), photoselective film (S), and photoselective film plus PGR (S + PGR). ${ }^{\mathrm{z}}$

\begin{tabular}{lcccccccc}
\hline & \multicolumn{4}{c}{ Dry wt $(\mathrm{g})$} & & \multicolumn{3}{c}{ Area $\left(\mathrm{cm}^{2}\right)$} \\
\cline { 2 - 4 } & Stem & Leaves & Bracts & Total & & Leaves & Bracts & Total \\
\hline $\mathrm{T}$ & $2.33 \mathrm{a}$ & $2.35 \mathrm{a}$ & $1.42 \mathrm{a}$ & $6.10 \mathrm{a}$ & & $1,032.4 \mathrm{a}$ & $911.0 \mathrm{a}$ & $1,943.4 \mathrm{a}$ \\
$\mathrm{T}+$ PGR & $2.33 \mathrm{a}$ & $2.56 \mathrm{a}$ & $1.27 \mathrm{a}$ & $6.16 \mathrm{a}$ & & $1,004.2 \mathrm{a}$ & $842.9 \mathrm{a}$ & $1,847.1 \mathrm{ab}$ \\
$\mathrm{S}$ & $2.23 \mathrm{a}$ & $2.31 \mathrm{a}$ & $1.41 \mathrm{a}$ & $5.95 \mathrm{a}$ & & $1,015.2 \mathrm{a}$ & $891.4 \mathrm{a}$ & $1,906.6 \mathrm{ab}$ \\
$\mathrm{S}+$ PGR & $2.28 \mathrm{a}$ & $2.15 \mathrm{a}$ & $1.06 \mathrm{~b}$ & $5.49 \mathrm{a}$ & & $942.6 \mathrm{a}$ & $831.8 \mathrm{a}$ & $1,774.4 \mathrm{~b}$ \\
\hline
\end{tabular}

${ }^{z}$ Different letters within columns indicate significant differences by Tukey's test at $P \leq 0.05$.

$\mathrm{PGR}=$ plant growth regulator. 
$\mathrm{T}+$ PGR (Fig. 6). No significant differences were detected between plants cultivated under photoselective film with or without PGR (Fig. 6).

In summary, our results show that light manipulation is an effective alternative to the application of PGR to control plant architecture in 'Freedom Red' poinsettias without affecting plant quality components under high natural radiation conditions of temper-

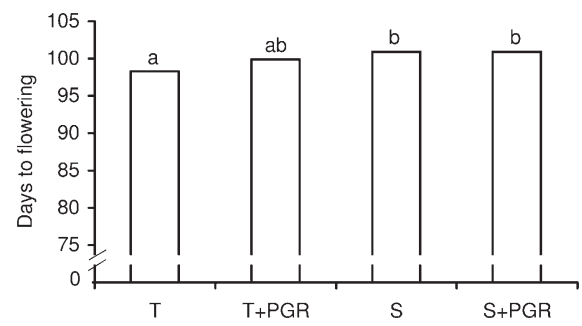

Fig. 4. Days to flowering of poinsettia plants cultivated under transparent film $(\mathrm{T})$, transparent film plus PGR (T+ PGR), photoselective film (S), and photoselective film plus PGR ( $\mathrm{S}+$ PGR). Different letters between columns indicate significant differences by Tukey's test at $P \leq 0.05 . \mathrm{PGR}=$ plant growth regulator.
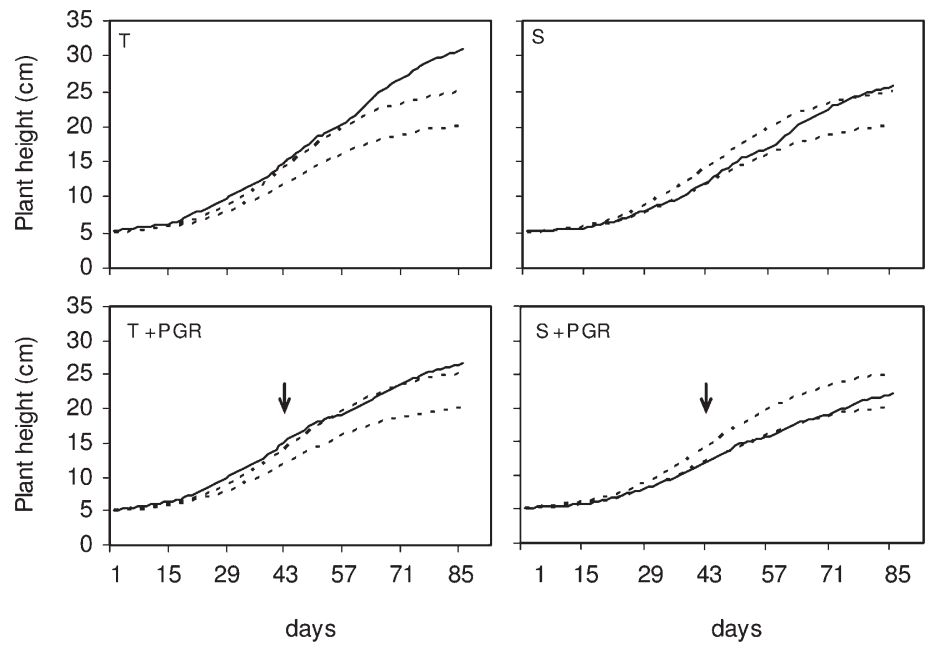

Fig. 5. Growth curves of poinsettia plants (solid lines) cultivated under transparent film (T), transparent film plus PGR (T + PGR), photoselective film (S), and photoselective film plus PGR (S + PGR). Dotted lines represent the range of the growing target curve defined by UNH FloraTrack for Poinsettia software. Arrows indicate the date of PGR application. PGR = plant growth regulator.
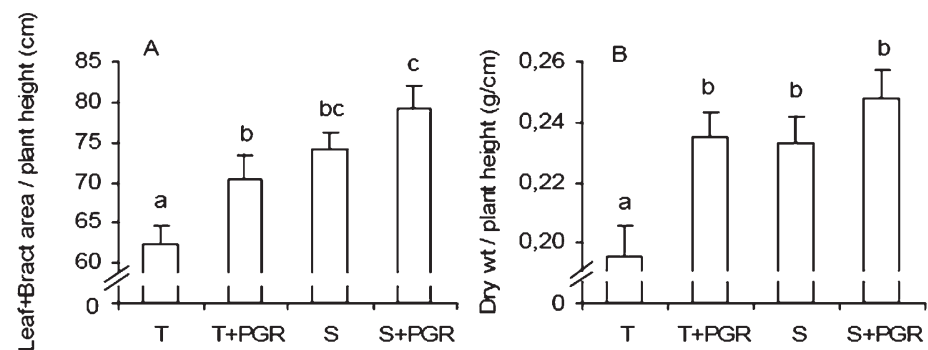

Fig. 6. Compactness indices expressed as area per unit plant height $(\mathbf{A})$ and dry weight per unit plant height (B) of poinsettia plants cultivated under transparent film (T), transparent film plus PGR (T + PGR), photoselective film (S), and photoselective film plus PGR (S + PGR). Vertical lines represent 95\% confidence interval. Different letters between treatments indicate significant differences by Tukey's test at $P \leq 0.05$. PGR $=$ plant growth regulator. promotes cell elongation of the vegetative structures (Lorrain et al., 2008).

High R/FR ratios and the use of GA inhibitors together might produce shorter and more compact plants (Fig. 6) with negative effects on the total area of leaves and bracts. Experiments designed to evaluate the PGR dose required to produce poinsettia plants under a photoselective film without affecting quality parameters as bract formation will be useful before recommending combined management practices of PGR and light. In addition, different cultivars of poinsettia will be tested to evaluate the generality of the conclusions of our results and the economic benefits of reducing the use of PGR in poinsettia production systems.

\section{Literature Cited}

Aukerman, M.J., M. Hirschfeld, L. Wester, M Weaver, T. Clack, R.M. Amasino, and R.A. Sharrock. 1997. A deletion in the PHYD gene of the arabidopsis wassilewskija ecotype defines a role for phytochrome $\mathrm{D}$ in red/farred light sensing. Plant Cell 9:1317-1326.

Berghage, R.D. and R. Heins. 1991. Quantification of temperature effects on stem elongation in Poinsettia. J. Amer. Soc. Hort. Sci. 116:14-18.

Cerny, T., J. Faust, D. Layne, and N. Rajapakse. 2003. Influence of photoselective films and growing season on stem growth and flowering of six plant species. J. Amer. Soc. Hort. Sci. 128:486-491.

Childs, K.L., F.R. Miller, M.M. Cordonnier-Pratt, L.H. Pratt, P.W. Morgan, and J.E. Mullet. 1997. The Sorghum photoperiod sensitivity gene, Ma3, encodes a phytochrome B. Plant Physiol. 113:611-619.

Clifford, S., E. Runkle, F. Langton, A. Mead, S Foster, S. Pearson, and R. Heins. 2004. Height control of Poinsettia using photoselective filters. HortScience 39:383-387.

De Lucas, M., J.M. Davière, M. Rodríguez-Falcón, M. Pontin, J.M. Iglesias-Pedraz, S. Lorrain, C. Fankhauser, E.T. Blázquez, and S. Prat. 2008. A molecular framework for light and gibberellin control of cell elongation. Nature 451:480 484.

Devlin, P.F., S.R. Patel, and G.C. Whitelam. 1998. Phytochrome E influences internode elongation and flowering time in arabidopsis. Plant Cell 10:1479-1487.

Faust, J. and R. Heins. 1996. Axillary bud development of Poinsettia 'Eckespoint Lilo' and 'Eckespoint Red Sails' (Euphorbia pulcherrima Willd.) is inhibited by high temperatures. J. Amer. Soc. Hort. Sci. 121:920-926.

Feng, S., C. Martinez, G. Gusmaroli, Y. Wang, J. Zhou, F. Wang, L. Chen, L. Yu, J.M. IglesiasPedraz, S. Kircher, E. Schäfer, X. Fu, L. Fan, and X.W. Deng. 2008. Coordinated regulation of Arabidopsis thaliana development by light and gibberellins. Nature 451:475-479.

Fisher, P. 2005. UNH FloraTrack: Graphical tracking for Poinsettia. Version 2.0f. Dept. of Plant Biology, UNH, Durham, NH.

Fletcher, J.M., A. Tatsiopoulou, M. Mpezamihigo, J.G. Carew, R.G.C. Henbest, and P. Hadley. 2005. Far-red light filtering by plastic film, greenhouse-cladding materials: Effects on growth and flowering in Petunia and Impatiens. J. Hort. Sci. Biotechnol. 80:303-306.

Huq, E. 2006. Degradation of negative regulators: A common theme in hormone and light signaling networks? Trends Plant Sci. 11:4-7. 
Izawa, T., T. Oikawa, N. Sugiyama, T. Tanisaka, M. Yano, and K. Shimamoto. 2002. Phytochrome mediates the external light signal to repress FT orthologs in photoperiodic flowering of rice. Genes Dev. 16:2006-2020.

Jacobsen, S.E. and N.E. Olszewski. 1993. Mutations at the SPINDLY locus of Arabidopsis alter gibberellin signal transduction. Plant Cell 5:887-896.

Kambalapally, V. and N. Rajapakse. 1998. Spectral filters affect growth, flowering, and postharvest quality of Easter lilies. HortScience 33:10281029.

Kasperbauer, M.J. 1987. Far-red light reflection from green leaves and effects on phytochrome mediated assimilate partitioning under field conditions. Plant Physiol. 85:350-354.

Kuehny, J.S. and P.C. Branch. 2000. Stem strength of Poinsettia. Acta Hort. 515:257-264.

Li, S., N. Rajapakse, R. Young, and R. Oi. 2000. Growth responses of chrysanthemum and bell pepper transplants to photoselective plastic films. Scientia Hort. 84:215-225.

Lorrain, S., T. Allen, P.D. Duek, G.C. Whitelam, and C. Fankhauser. 2008. Phytochrome-mediated inhibition of shade avoidance involves degradation of growth-promoting bHLH transcription factors. Plant J. 53:312-323.

McDaniel, G., E. Graham, and K. Maleug. 1990. Alteration of Poinsettia stem anatomy by growth retarding chemicals. HortScience 25:433-435.
McMahon, M.M. and J.W. Kelly. 1990. Control of Poinsettia growth and pigmentation by manipulating light quality. HortScience 25:1068. (abstr.).

Mortensen, L.M. and E. Stromme. 1987. Effects of light quality on some greenhouse crops. Scientia Hort. 33:27-36.

Mouradov, A., F. Cremer, and G. Coupland. 2002 Control of flowering time: Interacting pathways as a basis for diversity. Plant Cell 14 (suppl):S111-S130.

Rajapakse, N. and J. Kelly. 1992. Regulation of Chrysanthemum growth by spectral filters. J. Amer. Soc. Hort. Sci. 17:481-485.

Rajapakse, N. and J. Kelly. 1995. Spectral filters and growing season influence growth and carbohydrate status of Chrysanthemum. J. Amer. Soc. Hort. Sci. 120:78-83.

Runkle, E. and R. Heins. 2001. Specific functions of red, far red, and blue light in flowering and stem extension of long-day plants. J. Amer. Soc. Hort. Sci. 126:275-282.

Runkle, E. and R. Heins. 2002. Stem extension and subsequent flowering of seedlings grown under a film creating a far red deficient environment. Scientia Hort. 96:257-265.

Simpson, G.G. and C. Dean. 2002. Arabidopsis, the Rosetta stone of flowering time? Science 296:285-289.

Smith, H. 1981. Plants and the daylight spectrum. 1 st Ed. Academic Press, London, UK.
Smith, H. and G.C. Whitelam. 1997. The shade avoidance syndrome: Multiple responses mediated by multiple phytochromes. Plant Cell Environ. 20:840-844.

Snipen, L.G., R. Moe, and J. Sørleng. 1999. Influence of potential growth factors in predicting time to flowering in Poinsettia (Euphorbia pulcherrima). Scientia Hort. 81:345-359.

Valverde, F., A. Mouradov, W. Soppe, D. Ravenscroft, A. Samach, and G. Coupland. 2004. Photoreceptor regulation of CONSTANS protein in photoperiodic flowering. Science 303: 1003-1006.

van Iersel, M. and K. Nemali. 2004. Drought stress can produce small but not compact marigolds. HortScience 39:1298-1301.

Weller, J.L., N. Beauchamp, L.H.J. Kerckhoffs, J. Damien Platten, and J.B. Reid. 2001. Interaction of phytochromes A and B in the control of de-etiolation and flowering in pea. Plant J. 26:283-294.

Wilson, R.N., J.W. Heckman, and C.R. Somerville. 1992. Gibberellin is required for flowering in Arabidopsis thaliana under short days. Plant Physiol. 100:403-408.

Wilson, S. and N. Rajapakse. 2001a. Growth control of lisianthus by photoselective plastic films. HortTechnology 11:581-584.

Wilson, S. and N. Rajapakse. 2001b. Use of photoselective plastic films to control growth of three perennial salvias. J. Appl. Hort. 3:71-74. 